\title{
Promoting Efficiency and Contestability in Australia's Ports
}

\author{
Keith Trace
}

$\mathrm{H}$

ISTORICALLY, Australia's ports have been notoriously inefficient, forming the weakest link in the supply chain between Australia and its overseas markets. Despite numerous attempts at reform, productivity in container and breakbulk facilities remains low by international standards (Trace, 1991:15). In part, the inefficiency has arisen because Australian ports have been havens of monopolistic practices. Given the geography of the Australian continent, each of the capital-city ports has enjoyed a natural monopoly over an extensive area of hinterland; competition between ports has been limited to areas such as the Riverina and Northern New South Wales. Natural monopoly was reinforced by State ownership of port facilities and the non-competitive practices of State rail systems. Furthermore, cargo handling services have been provided by a single firm or by a duopoly in most ports, while towage and pilotage services have been in the hands of single providers.

The Waterside Workers' Federation (WWF) fought for, and subsequently successfully defended, its monopoly over the provision of waterside labour throughout Australia. Before 1989, waterside workers were employed on an industry rather than a company basis, and the waterfront had a long tradition of tradeunion militancy. Unreliability and low productivity, especially in container terminals and the handling of breakbulk cargo, detracted from the competitiveness of Australian producers. Since the cost of disruption was high for exporters and shipping companies alike, employers tended to give in to union demands, passing on the additional cost more or less automatically through higher stevedoring charges and freight rates.

Australia's bulk ports, in contrast, are relatively efficient. Whereas container and breakbulk facilities are controlled by a few service providers but used by many shippers, bulk handling facilities are controlled by a few service providers and typically used by a few large shippers. The relatively small numbers of bulk shippers are able to exert significant countervailing power. In other cases, bulk handling facilities are simply one stage in a vertically integrated production process, in which the vertically integrated company has an incentive to minimise cargo handling costs and the ability to control its costs.

Keith Trace is Associate Professor of Economics at Monash University. 


\section{Stevedoring Industry Reform Since 1986}

The costs of waterfront inefficiency have been recognised for many years, numerous commissions and inquiries having investigated the causes of low productivity. The most recent began in December 1986, when the Hawke Government asked the Inter-State Commission (ISC) to formulate an integrated industry plan for waterfront reform. The ISC's (1988) report stressed the urgency of reform, arguing that the industry suffered from abuse of monopoly power, introspective industrial attitudes, ineffective management, and poor workforce training schemes. The ISC recommended replacing the traditional industry-based labour pool with companybased employment, as well as reducing and rejuvenating the workforce by means of a special retirement and redundancy package, partially funded by government. The report recommended further that government should grant port authorities substantial autonomy, while retaining ministerial control over major investment decisions, pricing guidelines and rates of return; and it envisaged the Trade Practices Commission (now the Australian Competition and Consumer Commission) monitoring industry performance. The Hawke Government accepted the broad thrust of the proposals, and created the Waterfront Industry Reform Authority (WIRA) to implement its reform program. Beginning in 1989, the reform program was wound up in 1992.

The immediate outcomes of the stevedoring industry reform program appear limited, especially when compared with the outcomes of equivalent reform overseas. On the positive side, there was a sharp reduction in the stevedoring labour force, from 8,872 in September 1989 to 5,081 in June 1992, with a high proportion of eligible workers accepting redundancy packages. The waterfront also shifted from industry to company employment, although the negotiation of enterprise agreements proved difficult. The reform process was accompanied by significant productivity gains. Between 1989 and 1992, the number of containers handled per manshift increased by 88 per cent, and vessel turnaround time was reduced by 39 per cent (Prices Surveillance Authority, 1992:2). These productivity gains translated into a fall in the real cost of stevedoring: the Pricing Surveillance Authority's estimates suggested that the average cost of handling a 20-foot container fell from $\$ 254$ in 1990 to $\$ 190$ in 1992 . This price fall appears to be a result of the cost savings brought about by the reform program, but it may also reflect a fall in the volume of cargo handled by Australian ports as a result of recession. Stevedoring companies appear to have reacted to falling cargo volumes by 'sharpening their pencils'.

The WIRA reform program lost momentum in 1993-94, as the Keating Government seemed to lose interest in the waterfront. More disturbingly, Australian waterfront productivity declined in 1993 and 1994. A productivity league table, published by the container owner Contship for more than 40 ports worldwide, suggests that container handling rates in Melbourne fell from $26.7 \mathrm{teu} / \mathrm{hr}$ to 18.8 teu/hr in 1993, with the result that the port slipped from 20th to 34th position in the

${ }^{\mathrm{l}}$ Teu: 20 -foot equivalent unit. The standard shipping container measures 20 feet by eight feet by eight feet 
league table, while Sydney's handling rate fell from 19.9 teu/hr to $13.8 \mathrm{teu} / \mathrm{hr}$ (Australian Financial Review, 20 September 1994). In short, while port productivity improved during the WIRA period, there was a marked decline in productivity during 1993 and 1994.

Although container terminal performance in Australia improved in 1996, productivity is not significantly higher now than it was at the end of the WIRA process in 1992. In mid-1996, the crane rate, the most commonly used measure of productivity in container handling, averaged $20.3 \mathrm{teu} / \mathrm{hr}$ in mainland capital city ports, compared with $20.1 \mathrm{teu} / \mathrm{hr}$ in late 1992 (BTCE, 1996:2-5). However, crane productivity (the average number of containers moved per crane per working hour, not allowing for interruptions to the flow of work) averaged only 13.7 containers per hour during 1995. Yet productivity in overseas ports continues to improve: cargo handling rates in European, North American and Asian ports are generally higher, often significantly higher, than those attained in Australian ports (BIE, 1995:65ff). Thus, crane productivity rates at European ports visited by vessels operating direct Australia-Europe services averaged 20.0 containers per hour, or 46 per cent above the average for Australian ports (13.7).

Crane intensity (the average number of cranes used to work a ship) is generally lower in Australian than in major European, North American and Asian ports. Estimates for the Australia-Europe trade suggest that crane intensities, 1.7 in Sydney and 1.4 in Melbourne, compare unfavourably with 2.4 in Felixstowe and 2.0 in Rotterdam. Higher crane intensities in Europe and Asia are associated with larger numbers of containers exchanged at individual ports, and higher ship working rates. In general, Australian container terminals have fewer container cranes than major Northern Hemisphere ports, a consequence of the thinner trade flow. Poor crane rates and lower crane intensity mean that it generally takes 50 to 100 per cent longer to unload and load a container ship in Australia than it does in a comparable overscas port (BIE, 1995:xvi).

In contrast to New Zealand, where core reforms took place within a year, the Australian reform process has not only been protracted but remains incomplete. The ISC began investigations in 1986. Its report, calling for urgent reform, was released in 1989. A decade after it was launched, the reform process is unfinished, waterfront productivity remains relatively low and many problems remain to be resolved.

\section{Port Reform in New Zealand}

As suggested above, the Australian experience of reform contrasts markedly with that of New Zealand, where an historically inefficient port sector was shaken out of its lethargy by a reformist government. Before 1987, New Zealand's ports were

\footnotetext{
${ }^{2}$ Crane rate: the number of teus or containers moved per crane per net hour worked. Net hours worked allows for time during which work was not possible.

3

Crane productivity at Zeebrugge (26.2 containers per hour) and Tibury (23.5 containers per hour) was well above the highest figure for an Australian port, 14.9 containers per hour in Melbourne.
} 
administered by Harbour Boards under the aegis of the New Zealand Ports Authority. Most Boards were inefficient and uncommercial in approach, while competition between ports was discouraged. Wharf labour, employed on an industry basis with stevedoring companies bidding for the workers they required for a particular job, was administered by the Waterfront Industry Commission,

The Port Companies Act 1988 abolished the New Zealand Ports Authority and handed over control of ports to local government. Harbour Boards were replaced by port companies, which were required to operate on a commercial basis and pay dividends to Regional Councils. Inter-port competition was encouraged. Up to 49 per cent of shares in port companies could be held by the private sector (New Zealand Business Roundtable, 1989:4). While subsequent legislation permitted 100 per cent private ownership, the majority of port companies remain in the hands of regional councils.

Recognising that labour market reform was essential to raise waterfront productivity, the government introduced the Waterfront Industry Reform Act 1989, winding up the Waterfront Industry Commission, and replacing the labour pool system with an enterprise employment system (James, 1996:11). Under the Employment Contracts Act 1991, employers and employees must enter into employment contracts, which may be collective or individual, and unions no longer have exclusive rights to represent employees. Under this legislation, port companies have sought customised agreements that reflect their unique operational requirements. Most employers have sought and gained contracts containing some or all of the following conditions: flexible working hours; ordinary pay for the first $\mathbf{4 0}$ hours in any seven days; time off in lieu of overtime payments; unlimited use of casual labour; the right to use labour outside the confines of the wharf; and employment contracts of between two and three years' duration (Page, 1993:2-4).

The outcomes of the New Zealand waterfont reform program have been impressive. Substantial gains were achieved within a year and benefits have continued to flow. Port companies have become efficient and profitable operations. Competition between ports has increased (Auckland and Tauranga now compete for containerised cargo), forcing management to improve performance or face losses of throughput and revenue. Productivity has risen sharply. For example, the forestry industry has benefited from a sharp fall in stevedoring costs, and log carriers now load within two to three days compared with six to seven days previously. Similarly, New Zealand Associated Smelters has experienced significant decreases in stevedoring costs. Port charges have fallen. Employment has fallen significantly: before October $1989 \mathrm{New}$ Zealand had over 3,100 waterside workers, but only 1,300 several months later.

\section{Port Reform in the United Kingdom}

In the UK, as in New Zealand, port reform has included both changes in ownership and labour market deregulation. In its 1989 white paper Employment in the Ports: The Dock Labour Scheme, the government argued that British ports would face intense competition from European ports in the 1990s as a result of the Single 
European Market and the opening of the Channel Tunnel, and suggested that the abolition of the National Dock Labour Scheme (NDLS) would create a level playing field, enabling Britain's ports to compete more effectively (Turnbull \& Weston, 1993:109). The subsequent repeal of the Dockworkers (Regulation of Employment) Act 1946 and the abolition of the NDLS removed restrictive and archaic employment regulations, creating an environment favourable to the introduction of a range of flexible employment practices.

The Ports Act 1991 may be regarded as enabling legislation, providing for the transfer of statutory port undertakings (trust ports) to companies limited by shares and registered under the Companies Act 1985. The Act provided a further stimulus to the UK port privatisation program, which had begun with the creation of Associated British Ports (ABP) in 1983. By 1994, over 60 per cent of the tonnage handled by 'commercially-significant' ports was performed by privately owned ports.

The restructuring of UK ports has involved:

- decentralisation. operations have been broken up into smaller (strategic business) units. For example, port operations at Tilbury are sub-divided into six separate profit centres, with their own dedicated labour and management teams; and

- detachment typically, port authorities no longer own or operate stevedoring services, although they may retain some control through market or contractual relationships.

As Turnbull and Weston (1993:111) note, port authorities still control cargo movements through UK ports, but they do so through new contractual relationships or operational structures whereby cargo handling is now undertaken predominantly by small stevedoring firms.

The privatisation program has enhanced inter-port competition, as well as enabling port owners such as $\mathrm{ABP}$ to expand through the acquisition of a 49 per cent stake in Tilbury Container Services and the purchase of small ports such as Colchester and Teignmouth, and to diversify into non-port activities. The shortterm effect of the abolition of the NDLS has been to fuel competition within the industry. As in New Zealand, privatisation has also led to changes in the conditions of employment, including the introduction of individual contracts.

Benefits in terms of port efficiency and improved productivity have as yet to be fully documented. Anecdotal evidence suggests that the port reform program has been successful. In the Port of Tilbury, 950 workers handled 6.8 million tons of cargo in 1991, whereas a year earlier 1,800 workers handled 5.8 million tons. In other words, the port improved its throughput by 17 per cent with its workforce cut in half (Thomas, 1994:145). Most of the major ports in the UK claim significant improvements in productivity, mainly resulting from new working arrangements which offer greater labour flexibility, reduced staffing levels, and increased responsiveness to customer needs. 


\section{The Continuing Presence of Monopoly Power}

As noted above, most activities within Australian ports are highly concentrated, reflecting relatively thin trade flows and high costs of entry. Australian shippers typically face a chain of service providers, each of which has substantial market power. In Melbourne, for example, towage and pilotage services are provided by a single private-sector operator, although container terminal operations are currently offered by two suppliers. ${ }^{4}$ Moreover, since there is limited competition between ports, in part because of the high cost of land transport within Australia, shippers find it difficult to exert leverage on monopoly providers of port services.

Increased competition between ports would clearly help limit such market power. The potential market power of a port authority, and of the suppliers of services within ports, is constrained where shippers have alternative gateways for their cargoes. Although competition between Australian ports will always be limited by geography, lower-cost road, rail and coastal shipping services would enable users to switch cargo between ports more readily than at present. The removal of constraints on road-rail competition, the adoption of benchmarking aimed at enhancing efficiency in the provision of road, rail and coastal shipping services, the abandonment of cabotage and the opening of coastal trades to competition from foreign-flag shipping would expand the options available to shippers and enhance contestability. The current pricing structure for container and breakbulk shipping also discourages inter-port competition. Stevedoring charges, hidden within the total transport charge, lack transparency. Under the pan-Australia freight-rate regime, the rates to any given overseas destination are the same from all Australian ports, irrespective of differences in the relative efficiency and the costs of using the different ports.

Historically, the most significant monopoly has been that possessed by the WWF, now the Maritime Union of Australia (MUA). Waterfront unions, emboldened by their influence within the Australian Council of Trade Unions and the Australian Labor Party, have demonstrated their willingness and ability to wield monopoly power. Experience on the waterfront suggests that labour market reform is a necessary condition for improved port performance. New Zealand's experience also reinforces the importance of labour market reform. The Howard Government's Workplace Relations Act 1996 contains measures aimed at curbing union power, including the reinstatement of secondary boycott provisions based on Sections 45D and 45E of the Trade Practices Act. More generally, the legislation opens the way for existing employers to create a more competitive environment. The opening up of the labour market will also make it easier for new stevedores to enter the industry, perhaps bringing with them new attitudes and new ways of approaching old problems. One 'new kid on the block', Keon Stevedoring, has achieved record rates of timber loading in Brisbane, while Western Stevedores and Strangs provide competition in Fremantle and Melbourne.

\footnotetext{
${ }^{4}$ Melbourne Port Corporation announced in early 1997 that it had selected Hong Kong-based Orient Overseas Container Line to be the sole re-developer of Appleton Dock, thereby introducing a third container terminal operator (Daily Commercial News, 3 February 1997).
} 
The sequencing of port reforms has differed between Australia and New Zealand. Whereas New Zealand corporatised its ports and encouraged inter-port competition before undertaking labour market reform, Australia has undertaken labour market reform prior to undertaking reforms designed to enhance contestability and competition within ports. The danger inherent in the Australian approach is that, in the absence of vigorous competition or credible threat of entry, the benefits of labour market reform may flow to stevedoring companies and the MUA rather than to the consumers of port and shipping services. The sequencing of reforms may matter.

While labour market reform is a necessary condition for improved port performance, changes in ownership and incentive structures, designed to enhance contestability, appear vital. Unlike reform of the labour market, which is primarily a Commonwealth responsibility, changes in port ownership and contestability rest primarily with State governments and port authorities.

\section{Creating a More Contestable Environment}

The Victorian government's 'guiding principles' for reform of the port sector (Office of State Owned Enterprises, 1995:4) provide a convenient framework for discussing ownership and contestability:

- an environment should be created which encourages competition and the provision of services by the most effective provider;

- asset ownership should rest with the party able to make the best use of the asset;

- the private sector should have the predominant role in commercial service provision and port investment;

- non-commercial activities should be separated from commercial activities;

- monopolistic activities should be separated from competitive (or potentially competitive) activities wherever practicable; and

- consumer interest should be protected where market power is concentrated.

While Australian port authorities have adopted, in varying degrees, commercialisation and corporatisation, most remain subject to a range of operational and financial constraints imposed by State governments. Such constraints may include, inter alia : controls on port charges; ministerial direction, which may conflict with commercial decision making; obligation to undertake community services without compensation from government; limitations on borrowings; and public service conditions of employment. Such controls inhibit decision making, rendering it difficult for ports to operate in a commercial manner. Effective port reform requires 
that corporatisation and/or privatisation be undertaken further and more systematically.

The port reform program in Victoria, which builds on earlier corporatisation, provides one possible model for the future Australian-wide reform. A new statutory authority will act as 'landlord' in the Port of Melbourne, with responsibility for planning land use and berth development. While responsible for maintenance and planning, as well as the operation of common-user facilities, the port authority will not itself invest in new facilities. Onshore port assets at Geelong, Portland and Hastings will be sold, while underwater assets at Portland and Hastings are to be retained in public ownership and leased to the respective port owners. A new statutory authority (ChannelCorp) will be responsible for harbour control, the dredging of navigation channels and the provision of navigation aids. Non-core assets will be divested. The Victorian government has announced that it will encourage contestability in the provision of port services and establish an economic regulatory regime as soon as practicable.

Arguably, the board of a corporatised port itself has a real opportunity to enhance the level of competition and contestability. In the case of those functions historically performed by port authorities, typically dredging, maintenance, and ancillary services, boards should consider the relative merits of providing them inhouse as opposed to contracting them out. Such services could (and arguably should) be provided through a contestable market. The adoption of such a policy might require the establishment of a division or subsidiary company of the port corporation. This body would be required to: provide a defined range of services, creating a contestable market for each service; define a set of rules for tendering; and monitor the performance of successful tenderers.

Boards may also enhance the level of contestability in areas historically performed by the private sector (container terminal operations, towage and pilotage services). Greater contestability may be expected to lead to greater efficiency. In turn, greater efficiency will enable the port to expand its hinterland, increasing throughput and spreading fixed costs over a greater volume of cargo. A port's ability to enhance the contestability of container terminals is limited by the economics of terminal operation. Container terminal operations are characterised by relatively high capital investment (some unrecoverable on leaving the industry), economies of scale, and difficulties in obtaining suitable sites for new terminal development. Under such circumstances, contestability may best be promoted through the terms and conditions of the leases which the terminals obtain from the port landlord. Do existing leases promote efficiency and contestability? Do they provide for the monitoring of terminal performance? What sanctions exist if terminal performance is unsatisfactory? In practice, improvements in the terms and conditions of leases may have to be negotiated when those leases come up for renewal. Meanwhile, the existence of greenfield sites suitable for container terminal development may enhance contestability through the possibility of new terminal operators being introduced. 
Port corporations may also be able to promote a more contestable market in towage. The towage industry, which is concentrated at the national level, is characterised by significant barriers to entry and cooperative arrangements between the major operators (BTCE, 1989). Most capital city ports are served by a single operator, frequently a joint venture between the industry's two major players, Adsteam and Howard Smith. Following the takeover of J. Fenwick, Waratah Towage, jointly owned by Adsteam and Howard Smith, is the only tug operator in Sydney. Brisbane's towage services are provided by a single, privately owned firm, Queensland Tug \& Salvage Pty Ltd, which operates four tugs. The BTCE (1989) notes that Queensland Tug \& Salvage's net earnings were the highest of any Australian towage company during 1981/82-1986/7. The company may have been super-efficient, but the more likely explanation is that it was able to exploit its monopoly power.

The ability of a port authority to create a more contestable environment within the towage industry depends on the powers it possesses to impose economic regulation on towage operators. If a port corporation has the power to call for tenders for the provision of towage services, the remedy may lie in the development of an efficient tendering process designed to encourage contestability and economic efficiency. If a corporation does not have the power to call for tenders, it may be necessary to persuade government to regulate the towage industry.

Similarly, a port may be in a position to influence contestability in pilotage. Pilotage is normally provided privately, usually by associations. The issues raised when considering the contestability of the market for pilotage are similar to those raised for towage, except in so far as the provision of pilotage services is less capitalintensive and more labour-intensive. Boards should ascertain whether pilotage charges are 'excessive' and/or whether pilots are imposing 'unreasonable' terms and conditions on users. Pilotage may be under the control of the port authority or the State government. Contestability may be enhanced through an efficient tendering process.

We have noted that the transport chain through the ports is characterised by low levels of competition, many links in this chain (towage, pilotage, container terminal services) being controlled by monopolies or duopolies. Moreover, under Australian conditions importers and exporters usually have to use their nearest port. Under such conditions, notwithstanding our argument that governments and port authorities may be able to enhance contestability, an economic regulatory regime such as that proposed in Victoria is required to ensure that opportunities to capture excess profits at the expense of port users are not exploited.

The Victorian proposal gives the Victorian Office of the Regulator General responsibility for the economic regulation of the State's ports. Where the Regulator General is satisfied that effective competition exists, the office's role will be limited to periodic monitoring. However, where the Regulator General is not satisfied that competition is effective, the office's powers will extend to: the determination of maximum prices; investigation of price-related complaints; facilitating access to essential port facilities; and dealing with complaints concerning the abuse of market power. Under the Victorian proposal, the Regulator General will ensure shipown- 
ers and shippers access to monopoly and market-dominant assets and facilities, to guard against abuse of market power. The government notes that, while the access regime will protect the legitimate interests of owners of port facilities, such owners will be required to treat customers in a non-discriminatory way. For example, it will be illegal for the owner of a facility to charge vessels under its control a lower rate than it charges vessels owned by competitors or to give its vessels priority over competing vessels (Office of State Owned Enterprises, 1995:9).

\section{Privatisation}

While thoroughgoing corporatisation offers benefits, further privatisation of ports and/or privatisation of specific cargo handling facilities within corporatised ports creates the possibility of substantial productivity gains. Australia's privately owned coal and iron ore ports and/or loading facilities operate at or close to world best practice.

The benefits of privatisation are evident at the Port Kembla coal terminal. Before 1991, under the ownership of the New South Wales government, the Port Kembla coal terminal was inefficient, overstaffed and subject to frequent industrial disputes. Coal producers shipping through the terminal were disadvantaged by high handling charges and low productivity, giving rise to substantial demurrage (ship waiting time) charges. In 1991 the coal shipping subsidiaries of BHP, CRA, Austen \& Butta, Clutha, Denehurst and Oakbridge formed Port Kembla Coal Terminal Limited (PKCT). PKCT negotiated a 20-year lease on the terminal, with the option of a further 20 years, for a payment determined initially by the volume of coal shipped. The lease payments were designed to cover, over the 20 -year period, the terminal's book value $(\$ 192 \mathrm{~m})$, interest payments on that money, as well as a 'bonus' payment to the Maritime Services Board (MSB) of $\$ 117 \mathrm{~m}$.

By 1993 the benefits of privatisation were clear. The tonnage of coal handled by the terminal rose from the $10 \mathrm{~m}$ tonnes achieved by the MSB in the last year of public ownership to $15.6 \mathrm{~m}$ tonnes in 1991/92 and over $16 \mathrm{~m}$ tonnes in 1992/93. The terminal's productivity improved, allowing PKCT to cut its handling charges from $\$ 5.58$ a tonne to $\$ 4.27$. Vessel turnaround times improved and fewer ships incurred demurrage charges (Daily Commercial News, 21 January 1993).

\section{Conclusion}

Australia has yet to introduce thoroughgoing waterfront reform. While the early outcomes of the stevedoring industry reform program of 1989-92 were encouraging, momentum was lost in 1993 and 1994 and present productivity levels are little, if any, better than those achieved in 1992. Meanwhile, productivity in overseas ports has continued to improve, with the result that many ports in competitor countries achieve crane rates that are 25 to 50 per cent higher than those in Australian ports (BIE, 1995:73).

The consequences of waterfront inefficiency flow through the Australian economy. As the Bureau of Industry Economics (1995:34) notes, 'Australian exporters 
cannot demand a premium for their products simply because they use low volume Australian ports whereas their rivals may use a high volume, and potentially lower cost, port such as Rotterdam or Singapore'.

With reform of the labour market and institutional change aimed at enhancing contestability, Australia could realistically aim to raise its port productivity to levels achieved by the reformed New Zealand ports. It would be unrealistic to expect such reform to lift productivity to the world's best levels, such as Singapore achieves in its cargo handling. In part, this is the result of Australia's thin traffic flow: the limited container flows to and from Australia cannot sustain a high level of port investment. As a result, the average crane intensity per ship is much lower in Australia than in major hub ports, resulting in slower vessel turnaround.

However, thoroughgoing labour and product market reform should enable Australia to lift productivity to levels achieved by the best comparably sized overseas ports. This would imply raising crane rates from the 16-17 lifts per hour currently achieved in Sydney to the 30 lifts per hour achieved by ports such as Laem Chebang (Thailand) and Oakland (US). The first Australian port to improve its productivity significantly will gain a considerable competitive advantage, extending its hinterland at the expense of its competitors.

\section{References}

Bureau of Industry Economics (BIE) (1995), Waterfront 1995: International Benchmarking, AGPS, Canberra.

Bureau of Transport and Communication Economics (BTCE) (1989), Harbour Towage: An Analysis of Industry Performance, AGPS, Canberra (Occasional Paper No. 96).

- (1996), Waterline, Issue 7, Canberra (June).

Goss, R. (1987), Port Authorities in Australia, Bureau of Transport Economics, Canberra (Occasional Paper No. 84).

Inter-State Commission (1988), Waterfront Investigation: Conclusions and Recommendations, vol. 1, AGPS, Canberra.

James, M. (1996), Land of the Long White Benchmark: The New Zealand Reforms, Institute of Public Affairs, Melbourne (IPA Backgrounder 8(5)).

New Zealand Business Roundtable (1989), Ports and Shipping Reform in New Zealand, Wellington.

Office of State Owned Enterprises (Victoria) (1995), Reforming Victoria's Ports: A Competitive Future, Department of the Treasurer, Melbourne.

Page, G. (1993), 'Are New Zealand Port Companies Providing an Efficient Service?', paper delivered at a Ports and Harbours Conference, Auckland, April.

Prices Surveillance Authority (1992), Monitoring of Stevedoring Costs and Charges: Report No. 1, Melbourne (Monitoring Report No. 4). 
154 Keith Trace

Thomas, B. (1994), 'The Privatization of United Kingdom Seaports', Maritime Policy and Management 21 (2): 135-49.

Trace, K. (1991), 'Privatising Australia's Ports', Policy 7(1): 15-18.

Tumbull, P. \& S. Weston (1993), 'The British Port Transport Industry. Part 1: Operational Structure, Investment and Competition', Maritime Policy and Management 20(2): 109-20. 